\title{
PHILOSOPHY in the Dialogue of Democracy and Other Political Ideologies in the North African Revolutions
}

\author{
Celestine Chukwuemeka Mbaegbu \\ Department of Philosophy, Nnamdi Azikiwe University, Awka, Nigeria \\ Email: coopermbaegbu@yahoo.com
}

Received 16 August 2014; revised 18 September 2014; accepted 9 October 2014

Copyright (C) 2014 by author and Scientific Research Publishing Inc.

This work is licensed under the Creative Commons Attribution International License (CC BY). http://creativecommons.org/licenses/by/4.0/

(c) (i) Open Access

\begin{abstract}
The problems of social and political ideologies in North Africa have reached its apogee in the year 2011 thereby demanding urgent philosophical investigation. What is propelling this current change? What kind of scepter has been haunting North Africa for many decades now? What kind of political system could guarantee their rights since their hard-line monarchies have failed them and they are jostling for liberation? This value is antithetical to the prevailing ideologies that stand against their dream of a new order in that region. Using the method of analysis this paper sets out to unravel the root causes, analyze the consequences and point out the role of dialogue and philosophy in the current change. The conclusion is that the scepter of democracy, peoples' rights and freedom and clash of civilizations are behind these revolutions and that the most appropriate means of resolving the crisis is dialogue, not by hard power or any resolutions by the super powers.
\end{abstract}

\section{Keywords}

Philosophy, Democracy, Political Ideologies, Revolution

\section{Introduction}

Africa is the battle field on which military blocks, financial forces and ideological groups struggle for their own advantage and to the detriment of Africans. The North African revolution is of interest to the African people so long as it is a necessary step towards progress and not towards stagnation and retrogression. What is happening in North Africa is indeed evolution through revolution. The people of North Africa have been oppressed a great deal; they have been exploited a great deal, oppressed and have been disregarded a great deal. Now they have 
awakened from their slumber and have started revolutions which will lead to unprecedented political order, and stability in Africa.

The different protests are targeted towards the draconian rulers with long reigning despots, and who have ruled their countries without any sign of relinquishing power. However, it is obvious that the greatest political challenge facing Africa in general and North Africa in particular is the inability of the political leaders to see politics as service and this predominantly accounts for the reason behind so many dictatorial tendencies in governance in some of our African countries. Some of these leaders presumed to be empowered directly by Allah himself and this gave rise to dictatorship.

In view of the fact that revolutions have started, it becomes pertinent to use dialogue as a tool to curb such aberrations in Africa. All colonized African countries have to be revolutionary in their policies if they are to survive as a Third World. In the words of Paulo Freire the third world, is the world which was discovered, invaded, governed; then educated, converted and assisted, has at the same time being subjugated to discrimination. Thus, the world has been colonized and enslaved. But according to United Nations' (1948: Art.1) "all human beings are born free and equal in dignity and rights. They are endowed with reason and conscience and should act towards one another in a spirit of brotherhood". No African regime, whether conservative or revolutionary, dictatorial or democratic, is now safe from popular uprising, military coup or foreign intervention. Apparently, the fate of mankind seems to have fallen into the hands of self-seeking cynics, who are interested in maintaining their power and possessions and in the words of Dukor (2003: 226) "whose penchant for longevity in power runs like a genre in the blood of African leaders". Consequently, Kanza (1974: 56) observes that "money and personal glory are the ends most fervently pursued by modern men”.

Political stability as history reveals can be attained only if peoples and nations have the enabling environment that allow them freedom of expression, right to decent living, good education, freedom to determine or chart their destiny, association and peace movement and progress of the people. Consequently, the need for sound social and political system and terrain cannot be overemphasized because Africa as a multi-ethnic and religious state has to evolve or carefully apply some adequate political system that could take care of all these interests.

The political system most people think can guarantee these values is democratic system of governance. This is the general mood all over the world today. North African countries are being wooed to it and this is antithetical to hard-line monarchies which are the target of these protests to force them to succumb to their bid for their longings for political freedom. This is in consonance with the observation of Kanza (1974: 13) when he tries to portray why men of all ages revolt:

The human paradox has a positive side and a negative side—one may say-a creative power and a destructive power. Men pool their creative power in order to survive, and their destructive power in order to safeguard their interests and their rights. This instinct is the engine of the alliances formed by individuals and groups of individuals; it produces union into states and nations, the establishment of blocks and the formation of international communities.

This article therefore argues that the North African revolutions is a new phenomenon, a new problem and it needs a philosophical approach, the effectiveness of which can be measured by theoretical research and practical revolutionary activity. This is therefore, an inevitable extension of intellectual development, arising as a result of the characteristic of new epochs demanding a shift of philosophy to dialoging instead of pitting philosophy against a plurality of ideologies and clash of civilizations to dialogue with these values and the role of philosophy in the dialogue of these values themselves.

\section{Definition of Terms}

In order to make this article easy to understand, there is need for analysis cum systematic evaluation of data or information by breaking the basic concepts in this article so as to uncover their interrelations. The aim is to provide the basis for problem solving and decision making. In defining these concepts, we also gain knowledge or better understanding of a particular philosophical issue under consideration.

\subsection{Philosophy: A Formal Definition}

What is this subject that obviously occupies a special place as the preeminent human science? Our understanding of philosophy here corresponds to that given by Okere which goes beyond any narrow, elitist exclusivist un- 
derstanding and any of our merely regional, racial, epochal or cultural meanings of the term. Essentially, for Okere (2006: 2):

Philosophy here can be said to stand for the human effort to recapture, to imitate the truth and structure... of nature and reality. Philosophy is an effort to rearrange the world more geometric as Spinoza would teach, that is, logically and aesthetically to recreate the world, to impose a pattern on the chaos and tohuvobohu [turbulence] of life, of reality in the raw. It means humanizing our world i.e. rendering it reasonable, chasing away the impending chaos and tyranny of ignorance and of the absurd, the unreasonable, and the unthinkable. It is an arranging of the world and attuning it to the most human of man's faculties-intelligence.

Indeed, philosophy is a special discipline that seeks, finds and says the ultimate truth of things. Through critical analysis, critical assessment and comparative analysis, philosophy undertakes a scientific investigation in its bid to compare the Western traditional culture and the African traditional culture and in the words of Ekamolu (2006: 89):

This would reveal the features that are genuinely Western and those that are peculiarly African. It also affords us the opportunity to locate the points of overlap between the two cultures as well as give an understanding of the factors that facilitate the transition from the pre-scientific to the scientific period in Western society. In the final analysis, this can give some good insights into what is needed for scientific growth in Africa.

\subsection{Democracy}

The term democracy has a very long history. It dates back to the antiquities in the writings of Herodotus, in the works of Plato, especially in his book Politics, the word achieves its central classical meaning in the writings of Aristotle, especially in the book, Politics. Political theorists agree that unlike all other constitutional types of government, democracy is government that is driven by the general will of the majority. For this it is antithetical to dictatorship or any form of government that stands against human freedom. As a social and political theory of mass mobilization, its basic tenets were worked out by John Locke, J. J. Rousseau, and Montesquieu etc. The axioms of democracy enunciated by these political theorists have been applied and domesticated in the constitutions and practical governance of countries like the USA; several European countries, but the scope of its application still increases, especially since the end of the cold war and the disintegration of the former Soviet Union. This system of government is characterized by individual equality and freedom and Esheya (2006: 1) argues that:

Accordingly, citizens in a democracy should be entitled to equal protection of their persons, possessions and rights of political participation. Added to these the people should enjoy freedom from undue interference and domination by government. They should be free within the framework of the law, to believe, behave and to express them as they wish. Democratic societies seek to guarantee their citizens certain freedoms including freedom of religion, freedom of speech, freedom of press, etc. Citizens also should be guaranteed freedom of association and of assembly, freedom from arbitrary arrest and imprisonment and the freedom to work and live where and how they choose. Democracy therefore aims at giving man, the opportunity to develop what is finest in him.

This definition is in consonance with the definition given by the early American President Abraham Lincoln. According to him democracy is government of the people by the people and for the people. What is implied in this definition is that it works on the basis of representation, and has a structuring that is carefully worked out. This is clearly evident, looking at some political theorists like John Locke, etc.

For Locke and Montesquieu, democracy is founded on the natural rights of man to self-expression, conscience, association, integrity and possession of property. It relies on the principle of representation, which is brought about by the people exercising their free will in choosing who they consider fit to represent them. In the way they structured it, such representation is at three levels of government; the legislative, judiciary and executive arms of government. These three arms are to work harmoniously together by way of mutual complementation, with the legislative arm functioning as law makers, - laws which in turn must be binding on all. This three armed structuring functions by way of separation of powers, so unlike in the parliamentary constitution in which fusion of powers is recognized, the irreducible essence of democratic presidential system is to make for a more 
credible separation of powers among the three arms off government in a horizontal manner in such a way that no arm unduly encroaches into the functions of the other. Democracy as understood by majority of political theorists is a government in which the supreme power is vested in the people and exercised by them directly or indirectly through a system of representations usually involving periodically held free elections and is the noblest form of government we have yet evolved.

\subsection{Political Ideologies}

Okolo (1993: 2) in his scholarly work observes that:

Other forms of government in the history of man are polity or rule by the many but with some constitutional safeguards... oligarchy or the rule by a few who often seek control of the government for selfish purposes. Still others are: autocracy or the rule by a single person who generally assumes absolute or unlimited and selfish power. The ruler very often is a law unto himself; totalitarianism, which is absolute dictatorship in which absolute power rests with a single person.

The next form of government is referred to as timocracy which is rule by people that are held in high esteem or highly revered; government by men of rank and wealth. While still discussing the issue of who should rule, Okolo (1993: 2) advocates for:

Socialism or the government which espouses collective ownership of the means of production and the abolition of private property. Its different forms include communism, Marxism, Chinese collectivism, African socialism or communalism, etc. Lastly, we must not forget Tyranny which is the arbitrary and despotic rule by a government of one person with absolute power; and Fascism which is usually an autocratic regime headed by a dictator who as In the case of Hitler or Mussolini exalts the nation or the race above everything else.

\subsection{Revolution}

The term revolution is derived from a Latin word "revolutio" meaning "a turnaround". The term revolution has not enjoyed any universal definition and the contention among scholars of Social and political philosophy has been whether or not revolution should be violent or non-violent. Indeed revolutions can be political, economic, social, cultural, scientific, and religious. While some of these are non-violent in nature some are violent in nature. For instance, political revolutions are often violent inclined. It is a fundamental change in power or organizational structures. It may be as a result of a rebellion carried out with the intention of creating an entirely new form of government or any new cultural, social or technological paradigm; examples are the revolutions in North African countries, a major shift of political, socio-economic and cultural conditions.

A revolution is often referred to as violence. Connotatively, it is seen as a fundamental change in power or organizational structure that takes place in a relatively short period of time. However, it is an overthrow of a government or repudiation and the thorough replacement of an established government or political system by the people governed. The word revolution is used in many different contexts but it is usually meant to describe an aggressive overthrow of a government structure or social construct or a massive sudden change in societal upheaval. Little wonder Yoder (1926: 483) describes it as “one of the most used but often misused words. This assertion is so viewed as a calamity of the highest order, which must be avoided at any cost. In fact, news papers of the present day regularly refer to it as an outstanding catastrophe which faces modern nations”. It is a purely political phenomenon, a change in the location of sovereignty, an abrupt social change, in the entire social order, change so drastic as to involve all phases of the social organization. Revolutions are essentially characterized by a total change. A revolution generally represents a complete turnaround from one way of doing things to another way that is diametrically opposite. Most revolutions are motivated by the masses who have decided to use their advantage to overwhelm their own leadership. In some societies, oppression can continue for decades of years before the people decide to act against it, that is to topple dictators and poor leaders, and sometimes it is remarkably easy to do so. People sometimes use the word revolution in relation to technology and sometimes a new technological device will represent a revolutionary change. A good example might be the invention of the computer or the development of the Internet. Inventions like these can have the power to drastically change a society just as much as any political upheaval.

However, in this article, we are solely concerned with political revolution and chiefly as it affects the North 
African countries, namely: Libya where Muammar Gadhafi ruled for 42 years; Egypt's Hosni Mubarak’s 30 years reign. The next is Tunisia where Ben Ali ruled for 23 years before revolution swallowed him; Morocco where Mohammed V1 inaugurated his monarchic government on $23^{\text {rd }}$ July, 1999 till date; Algeria where AbdulAziz Bouteflika began ruling since 1999; and finally we have Sudan where Omaral-Bashir came to power in 1989.

The United Nations view North Africa as comprising 7 countries namely: Algeria, Egypt, Libya, Morocco, Sudan, Tunisia and Western Sahara. A comprehensive view of North Africa include all the countries classified by the United Nations plus the following geographically conterminous nations: Chad, Djibouti, Eritrea, Ethiopia, Mali, Mauritania and Niger.

\section{Causes and Consequences of the North African Revolutions}

At this juncture, let us analytically examine the root causes and the consequences of revolution so as to point out the role of dialogue and philosophy in the current change in the North African revolutions. The genesis of the North African Revolutions could easily be distilled from the wise statement made by Tom Mboya (1970: 2) an uncompromising champion of the struggle for Kenya's independence and freedom and indeed for the freedom of the whole of Africa which he styled "Crisis of Confidence".

In the field of international relations there is a crisis concerning the policy of non-alignment. Most of the developing nations, which have achieved independence since the Second World War, have declared themselves to be non-aligned. Yet all of them have found it difficult to implement this policy in practice. International relations are not a subject in which absolute right and absolute wrong are clearly defined. This is a lesson which the nations of Africa have quickly learned during their few years of independence. For example, there is no such thing as bilateral aid without strings. Nations need friends and friendship is a two-way relationship. And history has proved that it would be impossible to deny that such alliances have their dangers. Aid of any kind, and especially military assistance, has a way of bending the attitudes and policies of the recipient, however much he may protest to the contrary. Furthermore, it is only to be expected that the big powers will attempt to export their ideologies to other nations. In short, Mboya (1970: 4) insistently argues that these:

New nations seek to establish themselves in the world community as free, sovereign and independent states.

They want to have influence on world affairs. They want to establish an identity and image of their own.

There is need to be objective and to establish a reputation for independence and a sense of justice. They want to be taken seriously and refuse to agree that issues such as world peace, disarmament, etc. should be a monopoly of the super powers. They do not want to be subjected to the gravitational pull of any one of the power blocks.

The phenomenon of monopoly is characteristic of modern capitalist economies, whether based on private or state-owned property. Lenin observes that the birth of monopolies which is the result of the concentration of production is a general and fundamental law of capitalist evolution in the present stage. Initially, such cartels operate mainly on the national level. But with the present-day ease of communication and transport, and the increasing power of big capital to dominate markets, they have extended their influence beyond national frontiers, to produce powerful international monopolies. Faced with the need to protect their interests and rights, acquired or usurped, these monopolies in the words of Jules interfere in the political affairs of states which are economically, industrially or demographically weak, sometimes provoking local wars, insurrections or interventions. Practically, most industrialized countries are now subservient to their operations. And the struggle for the control of resources of the third world has not ceased. The monopolies are not content with the areas which they already control; their dynamism is increasing the concentration of capital and production.

Conservative dictatorship is part of the genesis of revolution in North Africa. Hence the revolution started as a struggle for the emancipation of the people from dictatorial governments. The revolution is nothing but a revolt against the government. Once in power they have behaved like bourgeoisie themselves and have thus produced a revolutionary generation, who also claim to be the representatives of the people and cry out to overthrow the successors of the colonial regime. Unless African dictatorial leaders learn that power is a means and not an end in itself, Africa may well become a continent of permanent revolution; a crisis ridden continent. But since independence, many African leaders have become conservatives and reactionaries. The entourage of North African politicians presents a generally dismal spectacle. Presidents, Ministers and political chiefs surround themselves with an assortment of upstarts, crooks and profiteers whose behavior is bound, to generate revolution. Agents of 
foreign powers are not absent from the presidential or ministerial entourage, provoking and sustaining intrigues with a ready supply of funds.

The historical, social, economic, cultural and ideological transformation which are taking place in North Africa make it clear that they are dissatisfied with any political system that deprives them of the opportunity to be architects of their destiny, but are interested in a system that ensures their freedom, rights, justice etc.

Although the international political system has become essentially polycentric, the Superpowers, through networks of command, control, and communications systems, nuclear threats, and interventions, have continued to shape not only the direction of world affairs, but also the character of conflict and revolutions in North Africa. Furthermore, the activities of NATO and the USA, France and Britain as purveyors of the most advanced Western capitalist technology have intensified the process of plunder, marginalization, social contradictions and immiserisation of the North African economies, their peasant farmers, creating and exacerbating security problems for all the countries in North Africa. Thus we can identify four major causes of revolution in North Africa: economic and military dependence, conflict and wars within states, inter-state antagonisms and conflicts and external great power intervention in North African affairs. Each of these threats or causes cannot be seen as an isolated problem but as inextricably entwined. It follows, therefore, that in formulating deterrence and defense strategies the interrelatedness of the threats, especially the ways in which they are internally and internationally linked, must be taken into consideration.

Intervention by outside powers in the affairs of the North African states presents one of the most serious threats to the North African peace, security and unity. Of all foreign interventions in North Africa, the USA, British and French stance are very unique. From the role of colonizers, they have switched to that of the guardian of their colonized states and lately have combined this role with that of Africa's gendarme (in Mauritania, Western Sahara, Chad, and Zaire). The uniqueness of the French case lies not so much in France's ability to combine these roles and at the same time to retain her credibility even outside the Francophone states as in the tenuous belief that France is not strictly speaking an external power both in and around Africa

The other two major Western powers, Britain and the United States, have intervened in Africa when there appears to have been any slightest threats to their economic interests, as in North Africa today. The North African countries are neo-colonial states par excellence, so that intervention in the revolutions is aimed as much to protect Western investments and sources of raw materials as to shore up regimes favorable to Western manipulation.

Perhaps what might be considered as the most important but hidden force driving the North African revolutions is the "Marxist" elements of the influence of economic forces on structure and the consciousness of African societies especially his "law of the negation of negation". According to Marx this is an extremely general and for this reason extremely comprehensive and important law of development of nature, history and thought, a law which holds good in the animal and plant kingdoms, in geology, in mathematics, in history and in philosophy. Negation is the inevitable and legitimate stage in any development. No development is possible without negation of its old forms of existence. This law does not mean the utter destruction of the old, but the normal process that takes place through continual destruction and amplified renewal. In the case of the North African revolutions, a new social system or ideology is trying to evolve from capitalism and communism of the West and again a new political system, monarchy is being negated to give rise to democracy and the negation will continue. In all a new form of African ideologies being sought for will evolve giving rise to something new more rejuvenated, purer etc. This does not mean utter destruction of the old, but must incorporate the material and cultural values created over preceding epochs. The law of the negation of negation demonstrates the progressive character of development as a rise from the lower to the higher, from the simple to the complex. Instead of lamenting their fate and stoically enduring their existence as exploited nations, the people of North Africa are engaging in deliberate action, conscious action to turn the political, the economic and their social world in a direction favorable to the full flowering of the human personality. But it must be pointed out that revolution for attainment of these values is necessary as against revolution for its own sake which is madness. The people of North Africa have definite, immediate and long-term objectives.

If we were to analyze the individual countries where this revolution is taking place today, to x-ray the root causes, and the consequences of the revolutions, it is an indubitable fact that most of them is as a result of the draconian rules of their long reigning despots who have ruled their countries without any sign of relinquishing power. In Tunisia where the maiden revolution started in $18^{\text {th }}$ December, 2010 it have their causes traced to the gruesomely symbolic suicide in December of Mohammed Bouazizi who some are calling "the father of the Tunisian revolutions", corruption, the graft and nepotism practiced by Ben Ali's family, the Trabelsis and Ben Alis 
were pillaging the country; unemployment and economic stagnation shrinking press freedom, and we might add other political freedoms. The consequences were unique, namely the immediate ouster of the president, killing of innocent civilians etc. In the Mediterranean Quarterly, Mohamed A. El-Khawu writing on Tunisia's Jasmine Revolution Causes and Impact: observes that it was to oust a long-time dictator who had ruled the country for twenty-three years new political parties were established and free and fair multi party elections were held, a giant step forward in the march towards democracy.

The second revolution in North Africa started in Egypt on $25^{\text {th }}$ January, 2011. The Egyptians who took to the streets to demand change came up to ten million. It was the largest popular movement in Egypt's modern history, and was considered as one of the largest on the history of the world over the last two centuries. The second revolution was grounded on police brutality of the masses, electoral fraud, and political censorship, and widespread corruption, high rate of unemployment, food price inflation, low minimum wages and lack of freedom on the side of the masses.

The effects the revolution produced and the changes it brought about included huge and radical changes on Egyptian reality, the most important being the overthrow of the regime that ruled Egypt with increasing repression for thirty years; shook the regime to its roots. It was also a "white revolution": the only blood split was at the hands of the regime and its cohorts, including a number of loyalists, business tycoons. The consequences were catastrophic since many protesters paid the supreme price of death by shading their blood. In short, the Egyptian revolution bears the essence of a popular uprising or any popular movement since it is described that it succeeds in rallying huge numbers under its banner and produces effects and brings about changes that impact strongly on the reality on the ground.

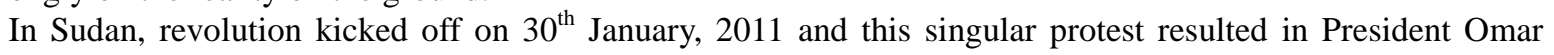
al-Bashir announcing his intention not to seek re-election in 2015. The protest took the forms of demonstrations, strike actions, riots, online activism etc.

The Algerian protest began on $20^{\text {th }}$ February, 2011 because of high cost of staple goods like sugar and oil and also because of corruption in the government. In response to the earlier violence and demands of civil society groups, the Algerian President, immediately promised moves to lower the prices of the goods and also provide government help in housing and job creation.

Libyan uprising started on $15^{\text {th }}$ February, 2011 and ended on $23^{\text {rd }}$ October, 2011. It was started because the masses were saturated with the dictatorial rule of Gadhafi and they want to exercise their freedom. The corruption of the Gadhafi administration had by the beginning of this $21^{\text {st }}$ Century become proverbial. Gadhafi and his children had run a thoroughly corrupt administration which had enriched their family and their cronies. By February 2011, discontentment had become widespread. There were, along with corruption, blatant human rights violations, the economy was in ruins, and unemployment was very high while the government treated all forms of opposition with an iron fist. Consequently, people of Libya wanted to democratize their government just like Egypt. Their leader was corrupt, and had been involved in diverse forms of corruption for many years. The people had no regard for him. They no longer wanted his rulership but they needed to have a say in what happens in their country. They chose not to be silent any longer for they were willing to die for freedom.

The revolution brought a marked change in the social and political order of Libya after the overthrow and killing of Muammar Gadhafi... weapons proliferation, Islamic insurgency, sectarian violence, and lawlessness have been problems and the spillover has affected neighboring countries including Mali. The interim National Transitional Council (NTC) declared that the country has been liberated in October 2011; it began a process to form a new government, prepare for elections and prosecute former Gadhafi officials. Elections were held in July 2012 to a General National Congress (GNC), which took power a month later. The NTC was dissolved, and in November Ali Zidan was sworn in as Prime Minister. Hundreds of protesters were killed during the period of the awakening.

The protest started in Morocco on the 20 $0^{\text {th }}$ February, 2011 and its aim is Constitutional Reform and the protest took the form of demonstrations and riots. The Moroccan government is now implementing Constitutional Reforms.

However, a critical study of these revolutions which sprang up in North Africa reveals that their major causes are: extreme poverty, authoritarianism, government corruption, human rights violations, inflations, kleptocracy, sectarianism, unemployment etc. The roles of the Western allies or superpowers show a greater element of imperialism, Neo-colonialism and egoistic tendencies. Former Head of state: Putin accused Western nations of hypocrisy for backing revolutions in North African countries that previously enjoyed their strong support. They are 
really arrogant world powers. But what is interesting is that they also supported the North African Revolutions as well as the ones that overthrew the old regimes. It is also good to note that the super-rich capitalists' countries have extracted enormous profits from this region of North Africa. At stake now are their oil wealth, military bases and critical channels for commerce. Rhys Merrett of Austria's National University said that the world powers intervention is largely for their national interests. The simple fact of oil is good enough reason to question the motives of any external state that intervenes. Physical intervention of any kind must not be an option. However, one can see that the role of the Western Superpowers in the North African Revolutions is largely imperial in nature. It is neo-colonialism and imperialism of the $3^{\text {rd }}$ Millennium because the super powers cannot play any role without gaining something in return. Their role is best to their own selfish interest and not in the interest of the countries where the revolutions are carried out.

In all, violent revolutions which culminated into wars in North Africa have been the most violating force in that region and Oyeshola (2005: 94) correctly observes that:

It continues to cause famine and the mass displacement of people. It causes mass migration and traumatizes young and old, women and men and the impersonal environment. The use of this power by individuals in robbery and for settling scores is multiplied a thousand times over as people in authority resort to it to settle political, social and economic challenges... The most obvious effects of political violence are the deaths and injuries resulting from it.

Other effects of the revolutions include: disruption of production and raising of operating costs, close down of businesses or reduction of production and investments. Again, hundreds of innocent people are being massacred which is a crime against humanity. Millions of people are forced to live a life without hope as refugees and displaced people. Worse still, in the impending wars in North Africa unspeakable terror is unleashed on the civilian populace, killing, raping, and maiming innocent people including women and children. Violent environment is another context within which the people of North Africa live move and have their being and they exert profound and untold influence on them now as they struggle to evolve domesticated ideologies that safeguard their freedom and rights.

On a positive note, the North African revolutions would usher in psychological, cultural, economic and political freedom in that region. Indeed the revolution would bring about economic well-being, respect for human rights and dignity, enthronement of democracy and technological advancement.

\section{The Role of Dialogue in the North African Revolutions}

By its nature, dialogue is a great instrument of peace. Dialogue is perhaps best exemplified by the Socratic dialogue, a discussion in search of agreement between two or more interlocutors. But it has its own game rules, its own finality, and its own conditions of fruitfulness. Thus it is not a talking to-a monologue. It is not pure information, or instruction or command. It is not a talking away from or a rambling around anything and everything. It is targeted at a precise subject matter. It is dominated by a question and answer, trial and error format. It is therefore a common search to arrive at the "truth", presumed not available as the monopoly of one party to be communicated or taught to the other. There is humility to it coming from the initial disavowal of omniscience and the a priori admission that may have something to learn from the other.

The dialogue is an appeal to reason, man to man, an appeal to that which makes man, which makes men one, to that rationality by which man stands out as a class apart in all creation-the paragon of animals, made just little less than a god. By appealing to that which most intimately makes man, unites man to man and distinguishes man from all else, it is preeminently designed to unite minds, cure ignorance and misunderstanding and discord and restore peace and harmony among men and people. What the dialogue does for men it can do for nations who are in any crisis with each other especially if mediated by philosophy.

This is why, in the resolution of the North African revolutions, by far the most fruitful and human strategy is dialogue. Dialogue, unlike a monologue, is respectful and affirming of the other. In eschewing both violence and the cannibalization of others, it refuses to violet the sacredness of others contrary to what is happening in North Africa. It creates a more just environment for mutual communication and assessment, for acceptance or rejection, for assimilation or differentiation, leading to a fairer and mutually more enriching exchange.

Dialogue offers the best chance to letting nations meet each other to touch or otherwise affect each other legitimately, while retaining their own sovereignty and integrity. For this reason, while in North Africa, there is a 
clash of ideologies and civilizations and others envisage a globalization in which one or two nations overrun and absorb the others, or where one nation milks the resources of the others in order to survive, we think that a more acceptable form of interaction is byway of dialogue, a dialogue in which philosophy can play a vital role.

The historical, social, economic, cultural and ideological transformations which are taking place in North Africa where the Western countries struggle for their economic motives make it clear that the North African countries must engage in the dialogue of persuasion to be allowed to develop a new original ideology, not a poor copy of either their political or social ideologies. It would be a mistake to assume that the African ideology will be based on the already existing Western ideologies which they themselves find it difficult to implement.

More importantly, the people of North Africa should engage their sit-tight leaders in a dialogue of persuading them to imbibe the culture of leaving the stage on the due date. The solution does not only lie in dialogue and what philosophy could do but the excessive incursions of the Western blocks into North Africa is likely to be abated if the leaders of these North African countries should stop selling oil to the West but none of these African Monarchs are ready to use this bounty given them as a means of fighting for their rights for example the Libyan and the Palestinian states. We are talking of philosophy as an enterprise and we imagine an enterprise of rationality dialoging that is, asking questions and giving answers to various ideologies, and the forms of government competing in that region. Each ideologies and political system would interrogate it, then interrogate the others and learn from them.

\section{Philosophy as an Indispensable Tool of Peace in the North African Revolutions}

Certainly, the clamor for democracy which is antithetical to the monarchical regimes in North Africa is one of the greatest causes of revolution in that region of Africa. The battle to enthrone democracy has been consistently resisted both by their home leaders as well as their colonizers. There are some other problems in North Africa: self-immolation of long reigning regime, wide-spread corruption in the government system, unemployment, blatant human rights violations, and intermittent interventions of super powers for whatever reasons, economic and military dependence of North African states on the industrial powers, ethnicism and racialism and crisis of identity. That philosophy is expected to contribute much here is based on the fact that philosophy is a critical and reconstructive discipline. Consequently, Oladijpo (1995: 5) argues that philosophy and indeed philosophers should put "philosophy in the service of human well-being through a critical and reconstructive scrutiny of the ideas we live by". More so, as Wiredu (1995:23) observes when "the fundamental concepts of philosophy are the most fundamental categories of human thought”. The implication of the above statements according to Oraegbunam (2006: 239) is that:

Philosophy must help in constructing a spirit of critical acceptance or rejection of ideas that are imported wholesale from Europe and America. Sometimes, these ideas do not fit into the African circumstances and labenswelt, but are accepted only on the blind supposition that everything European or American is the better.

Philosophy of education and or education for philosophy is therefore required to dispel this ignorance and poor mental self-appreciation of the African identity. Thus the role of philosophy within the comity of inter-disciplinary areas that will affect the task of pointing the way forward to the solutions to the problems that have bedeviled the North African States cannot be overemphasized. Here we should distinguish the reality of philosophy from the promise of philosophy; the one dealing with philosophy as we know it in history and in the history of international relations on the one hand and on the other, the promise it holds, the great hope it is pregnant with, the yet unachieved potential philosophy. The wisdom that philosophy seeks is one that tries to understand, to clear ignorance, to clarify obscurities, to establish reasonable mutually acceptable roles of conduct among individuals and peoples, minimizing the areas of friction and, where it cannot be completely eliminated, to promote mutual tolerance and avoid the reign of terror, violence and war among peoples.

Today there is resurgence in Africa regarding the adoption of democracy as a form of governance that has contributed to the successful growth and development of the society wherever it is practiced. The acceptance of democracy in Africa did not come about so easily. Today, at least every country in Africa is talking of adopting democracy, if not yet done. To some it is a matter of imposition. To others it is a matter of choice. Whether democracy is imposed or chosen, one thing is certain. The people of that society must learn to apply its principles so as to enhance productivity. Again, the seemingly industrialization going on in Africa is uprooting our sense of human dignity and the best person to understand the situation in Africa is the philosopher who has the capability 
to come out with the possibilities and opportunities that will assist in the positive growth of Africa. We must not shy away from the fact that majority of our people in North Africa do not understand what it means to be a human being. They have not contemplated deeply on the question "What is man" Standing on these premises Anov (2007: 239) reminds philosophers of their role in any society be it primitive or complex:

The contribution of philosophers in the society comes up readily by simple analysis and clarifications of the complex in use at a given time. Today, in Africa emphasis is placed on the process of democratization and development. How well do our politicians understand democracy as a political system of governance? To what extent are they ready to put into practice the principle of democracy for the common good of the generality of the people?

He therefore concludes that the philosopher must take enough time to make changes by the use of ideas. Philosophy is all about ideas and change; consequently, the philosopher must ginger the people to think responsibly and accountably since this way of thinking has brought positive changes in different parts of the world. This is the advantage of a philosophical thought pattern to humanity and must not be neglected in North Africa. Furthermore; philosophers in Africa must learn to provide insight to this group of people on the nature of man. This education will go a long way in reminding us of the aspects of life that are forgotten or taken for granted. He must earnestly persuade her people to look at life in a positive light. This is the only way people can be motivated to begin to appreciate themselves and others around them. The only way respect for human rights will have a place in the programs of our leaders. Anjov concludes on a very important note on the role of philosophy by saying that the Africa we hope to see in the nearest future greatly depends on the decisions we make today. We are capable of stimulating African leaders to conceive and implement planned economies, adapt democratic processes and appreciate the benefits of living in a pluralistic society. With particular emphasis on the choice of democracy that can work in the North African states, the philosopher must challenge its people to resist the temptation to plant liberal or participatory democracy on their soil as these are planned for the Americans and Britons in their different situations. North African nations have been under monarchical regimes and the concept of democracy, its principles and implementation should be inculcated before it can work. Governments in North Africa must therefore take education seriously. They must provide enabling environment for the intellectual training of her citizens so as to achieve self-realization as authentic human beings.

One of the ways which philosophers can be of help in the current revolutions in North Africa according to Wiredu (1972: 4) is through “comparative analysis” which involves three levels of analyses:

First, a critical analysis of traditional African culture with a view to identifying and separating the undesirable elements of culture from those that are desirable and worth keeping. Second, a critical assessment of Western culture and techniques, which is done with a view to identifying the aspects that are desirable and those that are suitable for social development in contemporary African society... The third level of analysis consists in the comparism of the Western traditional culture and the African traditional culture. This would reveal the features that are genuinely Western and those that are particularly African.

But it must be admitted that the philosopher or the philosophizing we are talking about here is the one that has the capacity to change theory into practice, a philosophy which can both comprehend and transform the world in contradistinction to the often quoted Marxian dictum that philosophers have only interpreted the world in many ways but without changing it. Okafor (2004: 61) therefore insist that apart from analyses "the contemplators of the African world and its condition must be the reformers as well”. Philosophies and indeed philosophers concerned with the North African revolutions should probe deeper into the causes and nature of these conflicts and prepare some action programmed to confront them. There must be a multi-disciplinary study of the North African revolutions which must culminate in setting strategies for curbing any crisis which has its genesis in the clash of ideologies and civilizations in North Africa and Africa as a whole. This is what it means by actionoriented study or philosophy of praxis which transcends theoretical denouncements of the situation and possible through action, constructive action, in the realm of practical affairs.

This period of human history could be designated as the "Dunciad", the age of the Dunces-the era of the reign of ignorance and stupidity that only philosophy and its wisdom can eventually end. Until then, the reign of terror continues with the North Atlantic Treaty Organization and the United Nations as constituted only an irreformably, undemocratic representation of unequal sovereignties or more precisely, since might is the main right, unequal proxies of unequal armies, all thinking and talking in terms of great powers and superpowers with their 
Veto powers, ganging up in shifty alliances in the United Nations often paid for in cash or exhorted by blackmail and, outside the United Nations constituting last nuclear armed alliances against only God knows who, in a future Armageddon that their very threat to the world makes rather probable than impossible.

\section{Conclusion}

No African regime, whether conservative or revolutionary, dictatorial or democratic, is now safe from popular awakening as is now being witnessed in North Africa. What is revealed in all these uprisings is that the people once awakened must of necessity win whether or not the ruling monarchs with their supportive Western allies internal or external act otherwise. And as we said earlier, the solution lies in dialogue or soft power and not by the barrel of the gun. Violence is not the best option for effecting a change in a society and it is obvious that most at times revolution goes with violence. In the annals of history, many people, nations etc. effected a change through non-violent means, For instance, Mahatma Ghandi and the co-Indians got their independence through nonviolent revolution, and the same can be said of Martin Luther King (Jnr.) and his fellow blacks (Negroes) in the New-world. They fought for the discrimination of the Negroes by the whites through non-violent means.

The nations of North Africa have rejected the Monarchical system of government and want to embrace democracy in which the masses are free to exercise their political freedom but the method of achieving this aim which is revolution with violence is not the right way or the best method for achieving the desired change. As men endowed with reason and the necessary faculties that accompany reason, the North African countries should have effected this change by gathering around the table of dialogue and applying the dialogic method.

The concept of power is a delicate and tragic phenomenon if and when subjected to an abusive end. It is like an elastic thread which can be stretched to any limit, but which definitely will have a breaking point and the men doing the stretching collapses. Hence, power can be used, over-stretched or overused to the point where the power holder collapses and breaks into pieces. This could result to a state of affairs which led former Tunisian leader Ben Ali to take to his heels and other monarchs of various North African Countries to meet their dead end.

\section{References}

Anov, T. K. (2007). Democracy and Conflicts in Africa: The Role of Philosophy in the 21st Century. In I. Odimegwu, \& G. Ezeani (Eds.), Philosophy, Democracy and Conflicts in Africa (pp. 220-241). Awka: Fab Anieh Nigeria.

Dukor, M. (2003). The Military and African Revolution. In M. Dukor (Ed.), Philosophy and Politics: Discourse on Values, Politics and Power in Africa. Lagos: Malthouse Press Ltd.

Ekamolu, A. (2006). Task of the Philosopher in Contemporary Africa. In R. A. Akanmidu (Ed.), Footprints in Philosophy (pp. 65-90). Ibadan: Hope Publications.

Esheya, E. G. (2006). Democracy and the Quest for Responsible Governance in Africa: A Philosophical Investigation. Enugu: Victojo Press.

Kanza, T. N. (1974). Evolution and Revolution in Africa. Cambridge: Schenkman Publishing Company.

Mboya, T. (1970). The Challenge of Nationhood. London: Heinemann.

Okafor, F. U. (2004). Matching Theory with Praxis to Confront the African Condition. In M. Asiegbu, \& J. A. Agbakoba (Eds.), Philosophy and Praxis in Africa (pp. 50-65). Ibadan: Hope Publications..

Okere, T. (2006). UNESCO World Philosophy Day: What Informed It and Why It Is So. In I. Odimegwu (Ed.), Philosophy, Democracy and Conflicts in Africa (pp. 1-15). Awka: Fab Anieh Nigeria.

Okolo, B. C. (1993). African Social and Political Philosophy: Selected Essays. Nsukka: Fuladu Publication Company.

Oladijpo, O. (1995). Introduction to Conceptual Decolonization in African Philosophy. Ibadan: Hope Publications.

Oraegbunam, I. K. E. (2006). Western Colonialism and African Identity: The Role of African Philosophy. In I. Odimegwu (Ed.), Philosophy and Africa (pp. 220-235). Awka: Lumos Nigeria Limited.

Oyeshola, D. O. P. (2005). Conflicts and Context of Conflict Resolution. Ile-Ife: Obafemi Awolowo University.

United Nations' Declaration of Human Rights Adopted by the General Assembly of the 10th December, 1948.

Wiredu, K. (1995). Conceptual Decolonization in Africa. Ibadan: Hope Publications.

Wiredu, K. (1972). On an Orientation in African Philosophy. Second Order, 2, 4.

Yoder, D. (1926). Current Definitions of Revolutions. American Journal of Sociology, 32, 433-441.

http://www.orgstable/2765544 
Scientific Research Publishing (SCIRP) is one of the largest Open Access journal publishers. It is currently publishing more than 200 open access, online, peer-reviewed journals covering a wide range of academic disciplines. SCIRP serves the worldwide academic communities and contributes to the progress and application of science with its publication.

Other selected journals from SCIRP are listed as below. Submit your manuscript to us via either submit@scirp.org or Online Submission Portal.
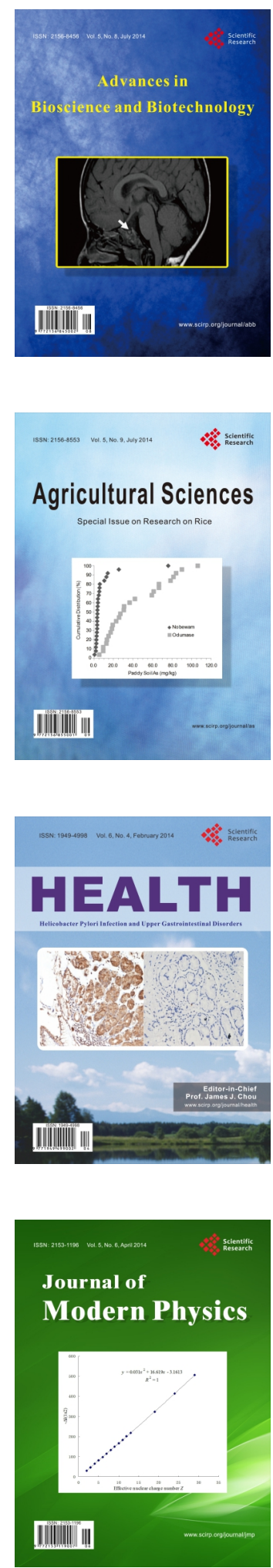
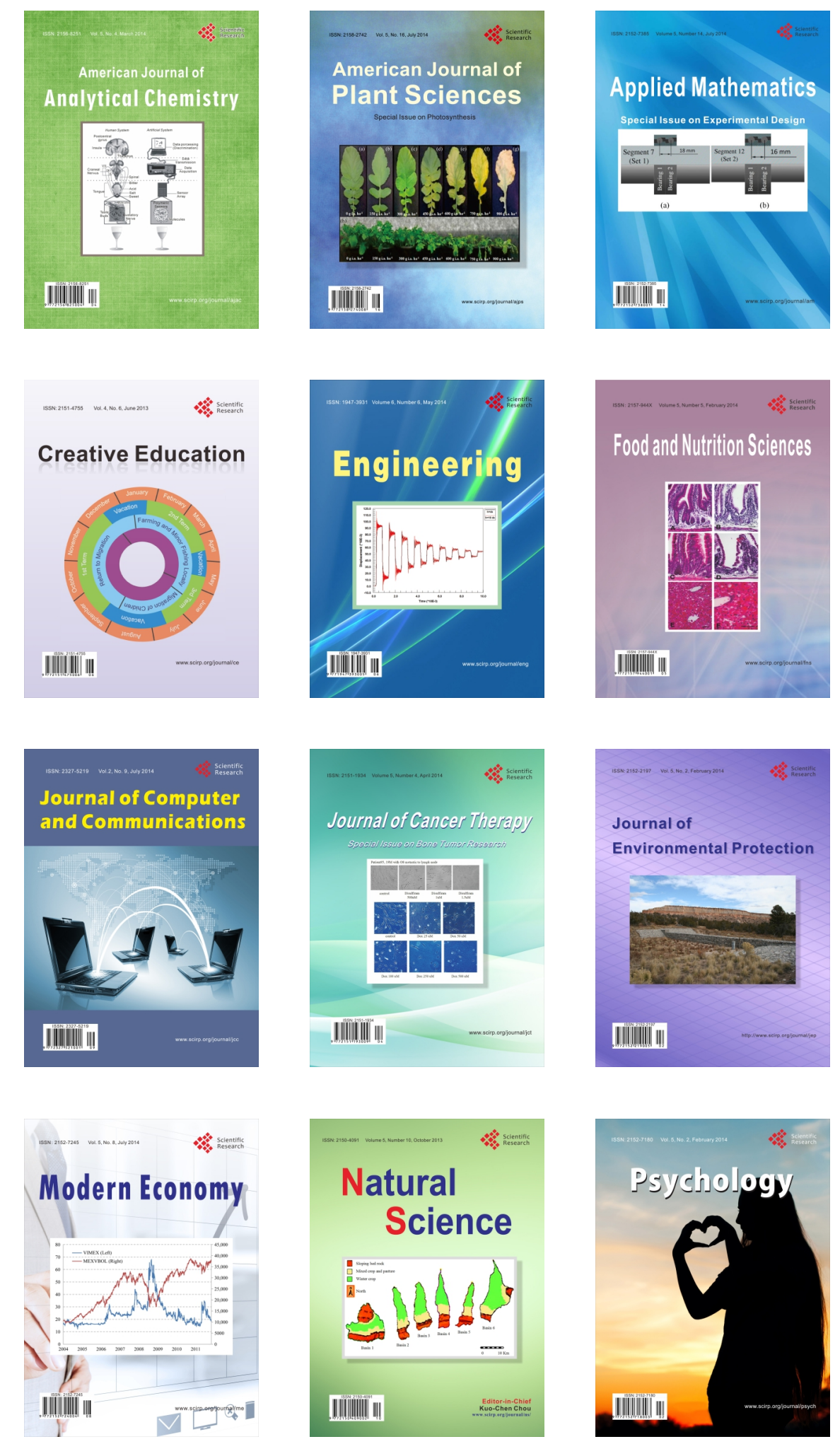